\begin{abstract}
Iranica
Abstracta Iranica Revue bibliographique pour le domaine irano-aryen

Volume 32-33 | 2013

Comptes rendus des publications de 2009-2010
\end{abstract}

\title{
Josette Elayi. Crises politiques dans les cités phéniciennes à l'époque perse
}

\section{Astrid Nunn}

\section{(2) OpenEdition}

1 Journals

\section{Édition électronique}

URL : http://journals.openedition.org/abstractairanica/40241

DOI : 10.4000/abstractairanica.40241

ISSN : 1961-960X

Éditeur :

CNRS (UMR 7528 Mondes iraniens et indiens), Éditions de l'IFRI

\section{Édition imprimée}

Date de publication : 1 décembre 2013

ISSN : 0240-8910

\section{Référence électronique}

Astrid Nunn, « Josette Elayi. Crises politiques dans les cités phéniciennes à l'époque perse », Abstracta Iranica [En ligne], Volume 32-33 | 2013, document 56, mis en ligne le 01 juillet 2016, consulté le 26 septembre 2020. URL : http://journals.openedition.org/abstractairanica/40241 ; DOI : https://doi.org/ $10.4000 / a b s t r a c t a i r a n i c a .40241$

Ce document a été généré automatiquement le 26 septembre 2020.

Tous droits réservés 


\title{
Josette Elayi. Crises politiques dans les cités phéniciennes à l'époque perse
}

\author{
Astrid Nunn
}

\section{RÉFÉRENCE}

Josette Elayi. «Crises politiques dans les cités phéniciennes à l'époque perse ». Trans., 39, 2010, p. 69-78.

1 Le volume Trans. 39 correspond aux Actes du VIII ${ }^{e}$ Colloque international sur les « crises et autres difficultés » de la Transeuphratène á l'époque perse. Pour les grandes cités phéniciennes, ce sont les crises politiques qui sont le mieux documentées. La situation politique la mieux documentée est celle concernant Sidon, les principales sources étant les inscriptions, les textes classiques et les monnaies. L'absence d'un héritier au début de l'époque achéménide, puis une rupture dynastique vers 425 av. J.-C. et enfin la révolte d'Abdaštart contre Artaxerxès III y ont initié des époques mouvementées. Tyr fut secoué par une crise d'ordre social avec la révolte des esclaves. À Byblos, le clergé tenta vers $400 \mathrm{av}$. J.-C. de prendre le pouvoir à la dynastie légitime.

\section{AUTEURS}

\section{ASTRID NUNN}

Université de Munich 